\title{
Kesuburan Perairan Berdasarkan Kandungan Nutrien pada Ekosistem Mangrove Desa Bedono, Demak
}

\author{
Aufa Rifqi Widiardja*, Ria Azizah Tri Nuraini, Diah Permata Wijayanti \\ Departemen IImu Kelautan, Fakultas Perikanan dan IImu Kelautan, Universitas Diponegoro \\ JI. Prof. H. Soedarto S.H, Tembalang,Semarang, Jawa Tengah 50275 Indonesia \\ ${ }^{*}$ Corresponding author, e-mail : aufa.widiardja@gmail.com
}

\begin{abstract}
ABSTRAK: Nutrien memiliki peranan penting dalam pertumbuhan dan perkembangan biota laut dan merupakan hasil uraian dari bahan organik kompleks. Secara alamiah konsentrasi nutrien dalam perairan bervariasi dan dalam kondisi tertentu dapat terjadi keadaan di luar batas optimal bagi organisme. Penelitian ini bertujuan untuk mengetahui kandungan nutrien (Nitrat, Nitrit, Ammonium dan Phosphat) dan mengetahui tingkat kesuburan perairan Desa Bedono, Kecamatan Sayung, Kabupaten Demak sehingga dapat memberikan informasi dan acuan dalam memonitoring kandungan nutrient di perairan. Penelitian ini dilaksanakan pada bulan Januari 2020 di Perairan Desa Bedono, Kecamatan Sayung, Kabupaten Demak. Metode dalam penelitian ini adalah metode deskriptif sedangkan pemilihan lokasi pengambilan sampel menggunakan metode purposive sampling method. Pengambilan parameter lingkungan yang dibutuhkan dilakukan secara insitu dan sampel air di analisis di Laboratorium Teknik Lingkungan, Universitas Diponegoro. Pengambilan sampel dilakukan tiga kali pengulangan dengan menyimpan sampel air dengan botol sampel polyetilene yang dimasukan kedalam coolbox untuk menghindari masuknya sinar matahari. Hasil penelitian menunjukan nilai analisis kandungan nitrat pada perairan Desa Bedono, Kabupaten Demak berkisar antara 2,353 - 2,973 mg/L. Kandungan nitrit berkisar antara $0-0,01 \mathrm{mg} / \mathrm{L}$, kandungan ammonium berkisar antara 14,815 - 18,239 mg/L, sedangkan kandungan phospat berkisar antara 0,04767 - 0,05133 mg/L. Berdasarkan kandungan nutrient Nitrat dan Phosphat kesuburan perairan berada dalam klasifikasi mesotrofik.
\end{abstract}

Kata kunci: Nutrien; Bahan Organik; Kesuburan Perairan

\section{The Enrichment of Water Based on Nutrient Content in the Mangrove Ecosystem in Bedono Village, Demak}

\begin{abstract}
Nutrient had an important role in growth and development of organism and are result of the decomposition from complex organic materials. Naturally, the concentration of nutrients in the water varies and under certain conditions it can occur outside the optimal limits that was declared safe for organism. This research aims to determine the level of water fertility based on the content of nitrate, nitrite, ammonium and phosphate in the Coastal Waters Of Bedono Village, Sayung District, Regency of Demak. This research was conducted on January 2020 in the Coastal Waters Of Bedono Village, Sayung District, Regency of Demak. The method used in this research is descriptive method while the selection of sampling location used the purposive sampling method. Taking the required environmental parameters conducted in situ and sample analysis conducted at Laboratorium Teknik Lingkungan, Universitas Diponegoro. Sampling is done by storing water samples with polyetilene bottles to avoid the entry of sunlight in three repetitions. The result of this research shows that the average range value of Nitrate content analysis at location is 2,353 $2,973 \mathrm{mg} / \mathrm{L}$. The average range value of nitrite content $0-0,01 \mathrm{mg} / \mathrm{L}$, for the average range value of ammonium content is $14,815-18,239 \mathrm{mg} / \mathrm{L}$, while the phosphate content ranged from 0.4767 $0.05133 \mathrm{mg} / \mathrm{L}$. Based on the nutrient content of nitrate and phosphate fertility waters at the level mesotrophic.
\end{abstract}

Keywords: Nutrient; Organic Matter; Fertility Waters

\section{PENDAHULUAN}

Ekosistem mangrove mempunyai banyak manfaat bagi ekosistem sekitarnya. Salah satu fungsi dari mangrove adalah memproduksi luruhan daun gugur (serasah) yang merupakan salah 
satu sumber bahan organik di perairan (Widhitama et al., 2016). Bahan organik sebagi sumber nutrien dapat berasal dari sisa - sisa tumbuhan mangrove berupa daun maupun batang yang tertimbun dan hasil dari hewan yang berasosiasi dengan mangrove, sehingga daerah mangrove tersebut menjadi subur (Fadmawati et al., 2017). Menurut Hartoko et al. (2013), bahan organik akan diuraikan oleh mikroorganisme menjadi nutrien atau unsur hara. Nutrien berupa bahan organik akan terdeposit dalam sedimen dan akan terdistribusi ke perairan oleh faktor lingkungan.

Nutrien merupakan zat-zat yang diperlukan dan mempunyai pengaruh terhadap proses dan perkembangan hidup organisme laut seperti lamun. Nutrien dimanfaatkan oleh organisme laut yang terdapat di permukaan maupun di kedalaman yang dapat dicapai oleh sinar matahari di mana proses fotosintesis berlangsung (Handayani et al., 2016). Nutrien di perairan terdapat dalam bentuk makro maupun mikro. Nutrien dalam bentuk makro terdiri dari: $\mathrm{C}, \mathrm{H}, \mathrm{O}, \mathrm{N}, \mathrm{S}, \mathrm{P}, \mathrm{K}, \mathrm{Mg}, \mathrm{Ca}$, Na, dan $\mathrm{Cl}$, sedangkan yang termasuk dalam bentuk mikro terdiri dari $\mathrm{Fe}, \mathrm{Co}, \mathrm{Zn}, \mathrm{Si}, \mathrm{Mn}$, dan $\mathrm{Cu}$. Nitrogen $(\mathrm{N})$, Phospat $(\mathrm{P})$ dan Silika (Si) merupakan nutrien yang memiliki peranan penting dalam pertumbuhan dan perkembangan organisme. Ketiga nutrient ini berperan penting terhadap pembentukan sel jaringan pada tumbuhan dan organisme laut seperti fitoplankton (Ridwan et al., 2018). Pertumbuhan, morfologi, kelimpahan, dan produksi primer tumbuhan pada suatu perairan umumnya ditentukan oleh ketersediaan zat hara fosfat, nitrat, dan ammonium (Setiani et al., 2019).

Meningkatnya aktivitas masyarakat di wilayah pesisir desa Bedono, dapat mengakibatkan berbagai dampak. Aktivitas tersebut dapat berupa kegiatan pemukiman, pariwisata, pabrik, pertambakan, masuknya sedimen atau limbah dari daratan, dan perusakan ekosistem mangrove. Aktivitas tersebut baik secara langsung maupun tidak langsung akan berdampak terhadap keseimbangan ekosistem di kawasan perairan. Kondisi ini dapat mempengaruhi kandungan nutrien yang terdapat di perairan Desa Bedono. Tidak optimalnya konsentrasi unsur hara akan mengakibatkan organisme tidak dapat bertahan hidup. Disamping itu, menurut Risamasu dan Hanif (2011), peningkatan maupun pengurangan nutrien di lingkungan perairan dapat berdampak positif jika jumlahnya sesuai dengan kebutuhan, namun pada tingkatan tertentu juga dapat menimbulkan dampak negatif. perubahan ekosistem pesisir seperti erosi pantai merupakan salah satu permasalahan yang dimiliki oleh daerah Bedono, Kecamatan Sayung, Kabupaten Demak. Berdasarkan uraian diatas, maka perlu dilakukan penelitian untuk mengetahui kandungan dan tingkat kesuburan perairan berdasarkan kandungan Nutrien dalam bentuk Nitrat $\left(\mathrm{NO}_{3}{ }^{-}\right)$, Nitrit $\left(\mathrm{NO}_{2}{ }^{-}\right)$, Ammonium $\left(\mathrm{NH}_{4}^{+}\right)$dan Phospat yang terdapat di perairan Desa Bedono.

\section{MATERI DAN METODE}

Penelitian dilakukan pada bulan Januari 2020 di Perairan Desa Bedono Kabupaten Demak Jawa Tengah. Materi penelitian yang digunakan untuk penelitian adalah sampel air dari perairan Desa Bedono, Kecamatan Sayung, Kabupaten Demak. Sampel air yang diambil digunakan untuk analisis kandungan Nitrat, Nitrit, Ammonium dan Phospat. Selain itu, terdapat pula data pendukung lainnya yaitu data dari kualitas perairan yang meliputi DO (Dissolved Oxygen), salinitas, pH (Derajat Keasaman), suhu, kecerahan dan kedalaman.

Metode penelitian yang digunakan adalah metode deskriptif yaitu metode yang memberikan gambaran secara sistematis, faktual, akurat mengenai faktor - faktor dan sifat - sifat dari suatu daerah atau populasi (Suryabrata, 1992). Metode deskriptif digunakan untuk memberikan gambaran tentang tingkat kesuburan perairan pada stasiun penelitian yang telah ditentukan. Data yang telah diperoleh selama pengamatan akan dianalisis secara deskriptif dengan membandingkan dengan klasifikasi tingkat kesuburan perairan dan standar baku mutu yang telah ditetapkan pemerintah dalam Keputusan Menteri Lingkungan Hidup No. 51 Tahun 2004 mengenai Baku Mutu Air Laut Bagi Kehidupan Biota.

Penentuan lokasi penelitian dilakukan dengan menggunakan metode purposive sampling method yaitu teknik pengambilan sampel yang didasarkan pada ciri atau sifat - sifat tertentu yang dipandang mempunyai hubungan erat dengan ciri dan sifat dari populasi dengan cara mengambil beberapa stasiun dengan pertimbangan keadaan lokasi yang memiliki sumber nutrient dan keadaan yang berbeda (Hadi, 1993). Penentuan stasiun dilakukan dengan melihat kondisi daerah penelitian, sehinggan stasiun pengambilan sampel dapat mewakili daerah penelitian secara keseluruhan yang meliputi Stasiun A sekitar ekosistem mangrove, stasiun B muara sungai dan stasiun C menuju laut lepas (Gambar 1). 


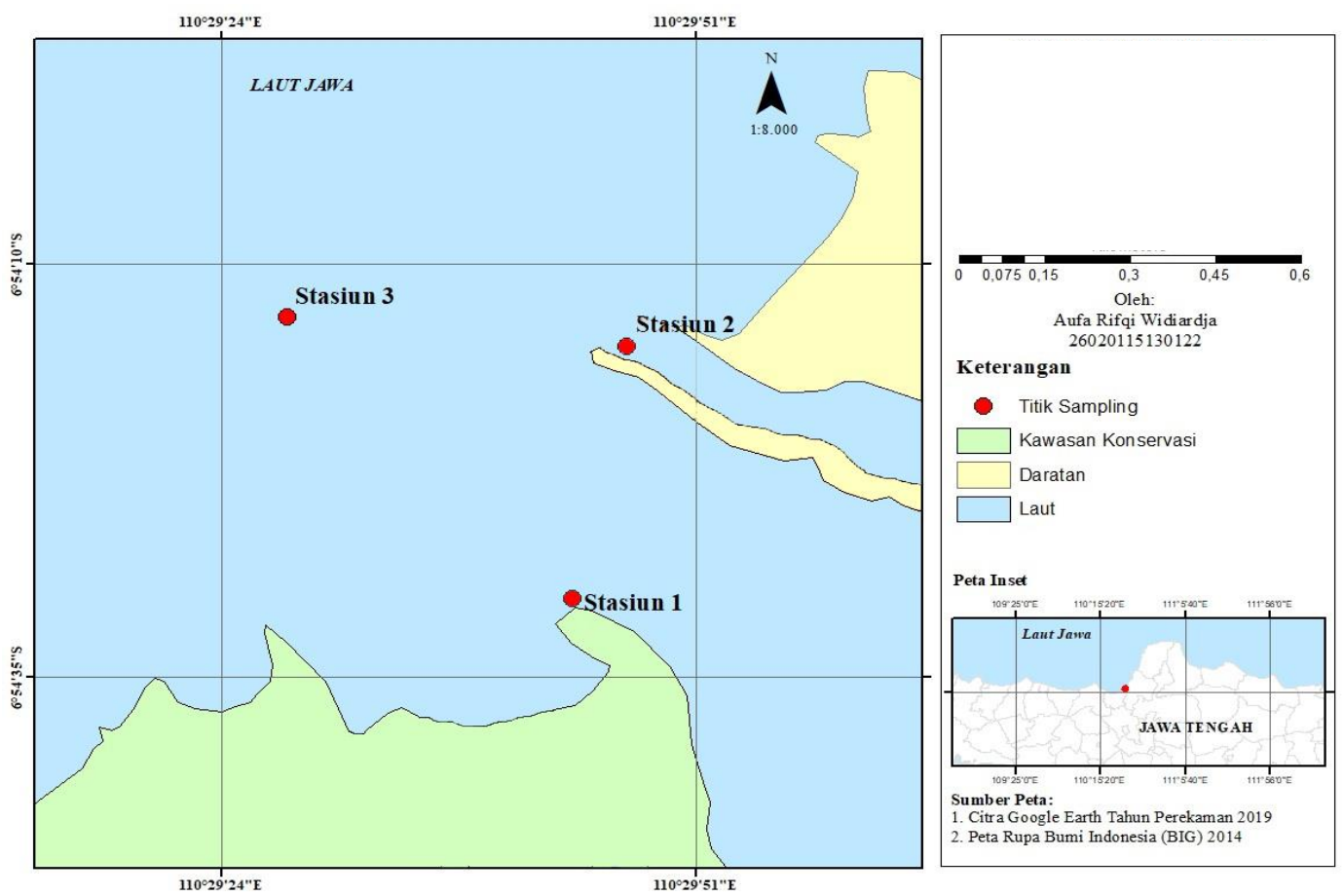

Gambar 1. Titik Sampling Lokasi Penelitian

Pengambilan sampel air dilakukan dengan cara memasukkan sampel air ke dalam botol polyetilene ukuran $500 \mathrm{ml}$. Sampel air di ambil dari permukaan air sampai 0,5 m hingga penuh, diusahakan jangan ada gelembung udara yang masuk kemudian botol sampel ditutup dengan rapat, diberi label dan dimasukkan ke dalam coolbox lalu dibawa ke Laboratorium Penelitian Teknik Lingkungan, Fakultas Teknik, Universitas Diponegoro untuk di analisis parameter Nutrien. Metode untuk analisa kandungan nutrien dilakukan dengan metode SNI 01-3554-2006 (Nitrat), SNI 06-6989.9-2004 (Nitrit), SNI 06-2479-1991 (Ammonium) dan SNI 02-0086-2005 (Phosphat). Metode pengukuran parameter lingkungan dilakukan secara insitu meliputi pengukuran DO (Dissolved Oxygen), salinitas, $\mathrm{pH}$ (Derajat Keasaman), suhu, kecerahan dan kedalaman. Pengukuran DO dan pH menggunakan WQC (Water Quality Checker), pengukuran suhu menggunakan thermometer, pengukuran salinitas menggunakan refraktometer, pengukuran kecerahan menggunakan secchi disk dan pengukuran kedalaman menggunakan batang kayu. Pengukuran parameter lingkungan harus dilakukan pada waktu yang sama dengan pengambilan sampel air untuk analisis Nutrien di setiap stasiun (insitu) menurut penelitian dari Ridwan et al. (2018).

\section{HASIL DAN PEMBAHASAN}

Nitrat adalah bentuk utama nitrogen di perairan yang dipengaruhi oleh proses-proses biokimia karena dihasilkan dari proses oksidasi senyawa nitrogen. Proses nitrifikasi untuk mengkasilkan nitrat dipengaruhi oleh beberapa faktor lingkungan perairan seperti oksigen terlarut, $\mathrm{pH}$, suhu perairan, dan salinitas (Widiyanti et al., 2018). Berdasarkan hasil analisa kandungan nitrat dalam sampel air laut yang diambil dari tiga lokasi di dapatkan hasil tertinggi pada stasiun A yang dekat dengan ekosistem mangrove dengan rata - rata $2,973 \mathrm{mg} / \mathrm{L}$, sedangkan hasil terendah di stasiun $\mathrm{C}$ yang lokasinya menuju ke tengah laut di dapatkan hasil rata - rata $2,353 \mathrm{mg} / \mathrm{L}$, stasiun B yang terletak di muara sungai di dapatkan hasil 2,857 mg/L. Perairan Desa Bedono yang memiliki kisaran kandungan nitrat 2,353 mg/L - 2,973 mg/L termasuk dalam perairan mesotrofik, karena menurut Wijayanto et al. (2015), klasifikasi perairan mesotrofik memiliki kisaran konsentrasi Nitrat sebesar 1-5 mg/L.

Tingginya kadar nitrat pada stasiun A dibandingkan dengan stasiun lainnya diduga karena bersumber dari serasah ekosistem mangrove dan stasiun ini lebih dekat dengan pesisir sebagai sumber masukan nutrien. Hal ini sesuai dengan pendapat Hutagalung dan Rozak (1997) yang 
menyatakan bahwa peningkatan kadar nitrat di perairan disebabkan oleh masuknya limbah domestik atau pertanian yang umumnya banyak mengandung nitrat. Pengambilan sampel yang dilakukan pada musim hujan juga diduga menjadi faktor tingginya kadar nitrat di lokasi penelitian karena air akan membawa suplai nutrien dari daratan. Pada stasiun B sumber nitrat adalah dari aliran sungai yang membawa masukan dari daratan karena lokasinya berada di muara sungai. Rendahnya kandungan nitrat pada stasiun $\mathrm{C}$ dibanding dengan stasiun lainnya sesuai dengan pendapat Risamasu dan Hanif (2011), yang menyatakan distribusi horizontal kadar nitrat akan semakin tinggi menuju ke arah pantai karena disebabkan oleh masuknya limbah dari daratan. Selain itu, lokasi stasiun $\mathrm{C}$ yang lebih kearah laut lepas dapat mempengaruhi kandungan nutrien karena adanya pengenceran dari air laut.

Konsentrasi nitrat di lokasi penelitian ini masih berada di atas standar yang baik untuk kehidupan biota laut menurut keputusan MENLH No.51 Tahun 2004 disebutkan bahwa konsentrasi nitrat air laut yang layak untuk kehidupan biota laut adalah 0,008 mg/L., sedangkan menurut Isnaeni et al. (2015) untuk pertumbuhan optimal fitoplankton memerlukan kandungan nitrat pada kisaran $0,9-3,5 \mathrm{mg} / \mathrm{L}$, sehingga kisara ini juga masih dalam batas optimal kandungan nitrat bagi fitoplankton. Hal ini ditemukan di seluruh stasiun penelitian dan mengindikasikan bahwa perairan ini memiliki kandungan nitrat yang baik bagi fitoplankton. Hal ini ditemukan di seluruh stasiun penelitian dan mengindikasikan bahwa perairan ini memiliki kandungan nitrat yang baik bagi fitoplankton. Hasil rata - rata kandungan Nitrat disajikan pada Gambar 2.

Nitrit merupakan bentuk peralihan (intermediate) antara amonia dan nitrat (nitrifikasi) dan antara nitrat dengan gas nitrogen (denitrifikasi) yang berlangsung pada kondisi anaerob dan Nitrit merupakan senyawa yang reaktif (Meirinawati, 2017). Berdasarkan hasil analisa kandungan nitrit di lokasi penelitian didapatkan hasil ditemukannya kandungan nitrit pada stasiun $B$ dengan konsentrasi 0,01 $\mathrm{mg} / \mathrm{L}$, sedangkan pada stasiun A dan 3 hampir tidak ditemukannya kandungan nitrit, hal ini disebabkan karena stasiun B yang merupakan muara sungai sehingga lebih banyak mendapat masukan dari daratan yang mengalir melalui sungai. Hal ini sesuai dengan pendapat Hutagalung dan Rozak (1997) bahwa kadar nitrit semakin tinggi menuju kearah pantai dan muara sungai. Ditemukannya kandungan nitrit pada stasiun $B$ dibandingkan dengan stasiun lain juga diduga karena lebih rendahnya kandungan oksigen terlarut atau DO pada stasiun B dibandingkan dengan stasiun lainnya. Rendahnya nilai DO di stasiun B dibandingkan dengan stasiun lainnya menandakan bahwa proses fotosintesis yang terjadi kurang maksimal, hal ini disebabkan karena rendahnya nilai kecerahan pada stasiun B paling rendah, sehingga penetrasi cahaya tidak dapat mencapai ke perairan yang dalam. Selanjutnya dinyakan oleh Sverdrup et al. (1942) dalam bahwa temperatur dapat mempengaruhi fotosintesis sebagai sumber oksigen di laut secara langsung maupun tidak langsung. Suhu di perairan Bedono berkisar antara 27 $30{ }^{\circ} \mathrm{C}$. Berdasarkan baku mutu optimal perairan air laut untuk biota laut dalam Keputusan Menteri Negara Lingkungan Hidup No. 51 tahun 2004, suhu yang terdapat di perairan desa Bedono masih memenuhi syarat untuk pertumbuhan dan perkembangan biota.

Stasiun C didapatkan hasil $<0,01 \mathrm{mg} / \mathrm{L}$ sedangkan pada stasiun A tidak ditemukannya kandungan nitrit. Data ini menunjukan bahwa secara umum konsentrasi nitrit di perairan desa Bedono, Kabupaten Demak tergolong rendah karena hampir tidak ditemukannya nitrit pada stasiun A dan 3 sedangkan pada stasiun B ditemukan tetapi jumlahnya hanya sedikit dan masih dibawah batas maksimal dari nitrit yang diperbolehkan terkandung dalam perairan. Tidak tersedianya konsentrasi nitrit disebabkan oleh oksigen yang tersedia cukup baik karena kadar oksigen terlarut di lokasi penelitian berada di kisaran 5-6,5 mg/L yang termasuk di atas standar baku mutu. Optimumnya konsentrasi nitrat juga diduga karena perombakan nitrit menjadi nitrat dengan bantuan bakteri berjalan dengan baik. Hal ini sesuai dengan pendapat dari Risamasu dan Hanif (2011) yang menyatakan bahwa dengan bantuan bakteri, oksigen akan mengoksidasi nitrit menjadi nitrat sehinggan konsentrasi nitrit akan sedikit. Menurut Ridwan et al. (2018), kandungan nitrit yang tinggi dalam air yang sedikit mengandung ion klorida akan menyebabkan berkurangnya aktivitas makan, penurunan daya tahan terhadap penyakit serta terjadinya kematian pada organisme. Akumulasi nitrit dapat terjadi akibat dari tidak seimbangnya kecepatan perubahan nitrit menjadi nitrat. Jika kadar oksigen dalam air tinggi maka nitrit akan teroksidasi menjadi nitrat sedangkan jika kadar oksigen rendah maka nitrit akan tereduksi menjadi N bebas. Hasil rata - rata kandungan Nitrit disajikan pada Gambar 3.

Bentuk reaktif nitrogen yang lebih dikenal adalah amoniak $\left(\mathrm{NH}_{3}\right)$ yang terlarut dan membentuk $\mathrm{NH}_{4}$. Senyawa ini merupakan senyawa esensial untuk produksi mikroorganisme perairan. Pengurairan ini dikenal sebagai proses nitrifikasi (Yanti, 2017). Nitrifikasi adalah proses perubahan amonia menjadi 


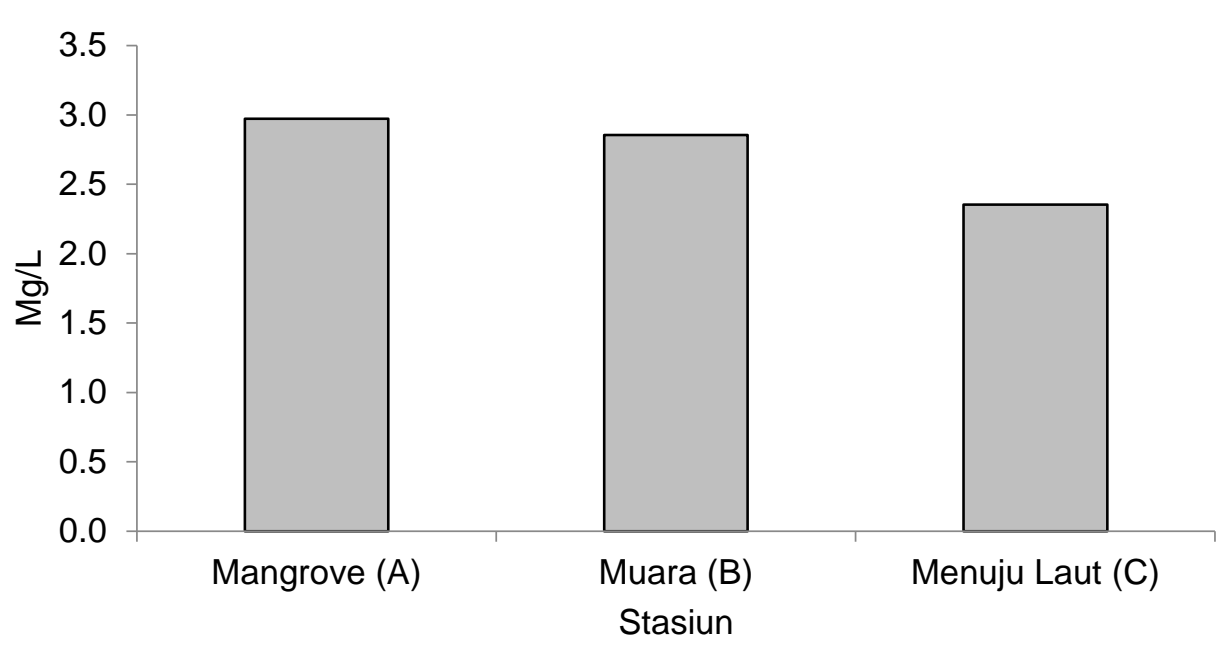

Gambar 2. Kandungan Nitrat pada Perairan Desa Bedono

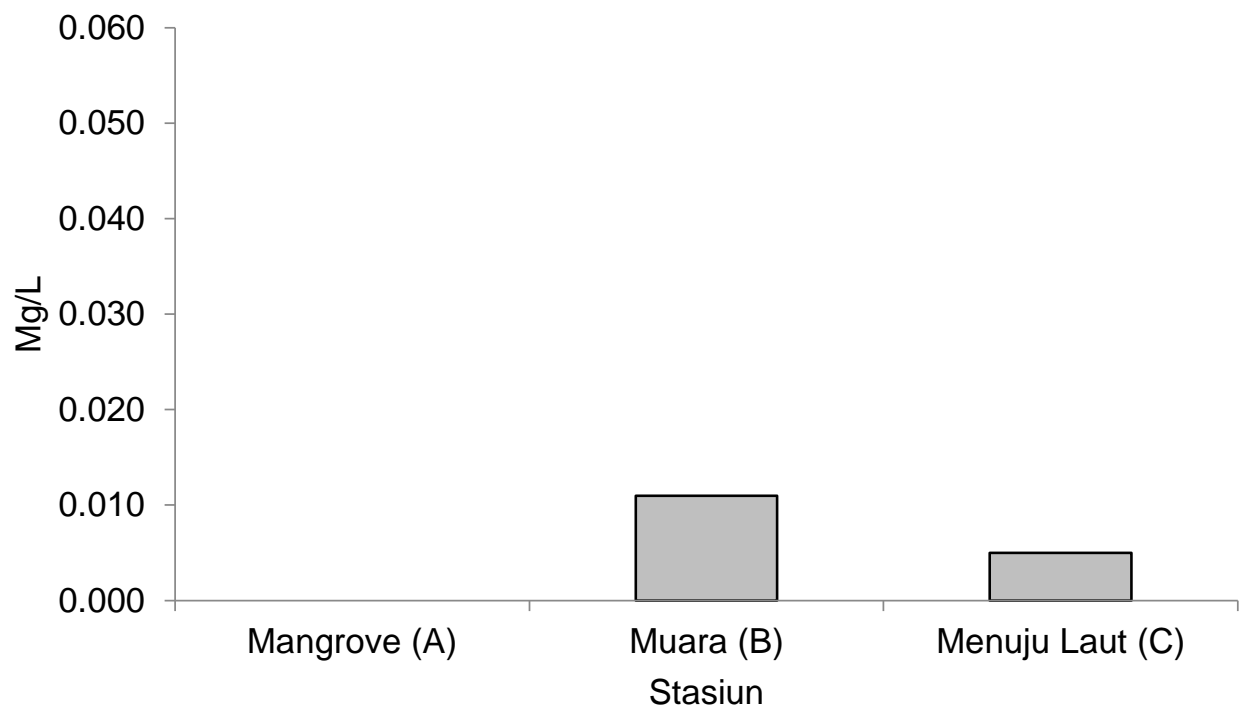

Gambar 3. Kandungan Nitrit pada Perairan Desa Bedono

nitrat, melalui dua langkah proses aerobik. Langkah pertama adalah oksidasi amonia menjadi nitrit dan langkah kedua nitrit teroksidasi menjadi nitrat (Meirinawati, 2017). Hasil pengukuran kandungan Ammonium di dapatkan rata - rata konsentrasi ammonium berkisar antara 14,815 - 18,239 mg/L. Tingginya kandungan ammonium diduga karena terdapatnya sumber bahan organik dari ekosistem mangrove, selain itu diduga karena dilakukan pengambilan saat musim hujan sehinggan menyebabkan banyaknya sumbangan dari daratan yang dibawa oleh air hujan yang masuk ke perairan. Menurut Kurniawan et al. (2016) cairan buangan dari limbah rumah tangga rata - rata mempunyai kandungan nitrogen sebesar $20-85 \mathrm{mg} / \mathrm{L}$ dan sekitar $60 \%$ merupakan nitrogen ammonia, sisanya merupakan nitrogen organik seperti nitrat dan nutrien lain, peningkatan kadar ammonium di perairan disebabkan oleh adanya masukan limbah domestik, perternakan, industri yang umumnya banyak mengandung bahan organik. Nilai pH di lokasi penelitian berkisar antara $7-7,6$ dan suhu berkisar antara $27-30 \stackrel{\circ}{\circ}$. Menurut Ridwan et al. (2018), pada pH 7 atau kurang maka sebagian besar amonia akan mengalami ionisasi menjadi $\mathrm{NH}_{4}$. Komarawidjaja (2003), menjelaskan bahwa semakin cepat proses reaksi nitrifikasi menyebabkan terjadinya penurunan $\mathrm{pH}$, karena pada rekasi nitrifikasi akan menghasilkan 4 ion $\mathrm{H}+$ (dalam pengubahan ammonium menjadi nitrit). Hasil rata - rata kandungan Ammonium disajikan pada Gambar 4.

Hasil analisis phosphat yang dilakukan di dapatkan hasil pada stasiun A sebesar 0,04767 
$\mathrm{mg} / \mathrm{L}$, lalu pada stasiun $\mathrm{B}$ sebesar $0,05 \mathrm{mg} / \mathrm{L}$ dan yang tertinggi terdapat pada stasiun $\mathrm{C}$ dengan kandungan phospat sebesar $0,05133 \mathrm{mg} / \mathrm{L}$. Kandungan phosphat di tiga stasiun sudah melebihi batas kisaran optimum untuk kehidupan organisme menurut Kementerian Lingkungan Hidup sebesar 0,015 $\mathrm{mg} / \mathrm{L}$. Kandungan phosphat yang sudah melebihi batas kisaran optimum ini dikarenakan terdapatnya ekosistem mangrove di sekitar perairan. Hal ini sesuai dengan pernyataan dalam jurnal penelitian Ridwan et al. (2018) yang menyatakan bahwa sumber utama bahan organik di perairan adalah serasah yang dihasilkan oleh tumbuhan mangrove (daun, buah, ranting, dan lain-lain), kemudian bakteri dan jamur menguraikan bahan organik dalam tanah dan perairan lalu melepaskan fosfat anorganik. Selain itu masukan erosi tanah dari daratan yang terbawa aliran sungai juga menjadi sumber fosfat di perairan. Sumber alami fosfor diperairan adalah pelapukan batuan mineral. Hal ini juga dikemukakan oleh Permatasari et al. (2016), bahwa dasar perairan selalu kaya zat hara, selain berasal dari dasar perairan itu sendiri, juga dari sumbangan dekomposisi detritus dan mangrove yang ada di sekitar perairan. Menurut hasil penelitian Gurning et al. (2020), lebih tingginya kandungan phospat pada stasiun $\mathrm{C}$ dibandingkan dengan staiun lainnya sejalan dengan tingginya kelimpahan fitoplankton dibandingkan dengan stasiun yang lain. Hal ini berarti kelimpahan fitoplankton pada perairan Desa Bedono dipengaruhi oleh nutrien phospat dibandingkan dengan nitrat. Hal ini sesuai dengan pendapat Subiakto et al. (2019) yang menyatakan bahwa Phospat adalah bentuk fosfor yang dapat dimanfaatkan oleh tumbuhan dan merupakan salah satu unsur esensial bagi tumbuhan tingkat tinggi dan alga sehingga phospat dapat mempengaruhi tingkat produktivitas perairan. Perairan Desa Bedono termasuk dalam klasifikasi mesotrofik karena berada di kisaran 0,02-0,05 mg/L. Hasil rata - rata kandungan Phosphat disajikan pada Gambar 5.

Hasil pengukuran parameter kualitas air selama penelitian beserta data parameter sekunder di tiga stasiun Perairan Desa Bedono pada bulan Januari 2020 selengkapnya disajikan pada Tabel 1 di bawah. Data parameter fisika dan kimia menunjukkan bahwa nilai $\mathrm{pH}$ dan salinitas tidak terdapat variasi yang mencolok. Nilai pH berkisar dari $7-7,6$ dengan nilai tertinggi pada stasiun $\mathrm{C}$ (Laut Lepas) sebesar 7,6 sedangkan pada stasiun B dan A nilai pH nya adalah 7 dan 7,2. Nilai salinitas pada perairan berkisar antara $20-27 \%$. Nilai suhu dari stasiun Berkisar dari $27-30{ }^{\circ} \mathrm{C}$. Nilai kecerahan pada tiga stasiun sangat bervariatif dengan kisaran $20-33 \mathrm{~cm}$, stasiun C (Laut Lepas) memiliki nilai kecerahan tertinggi yaitu $33 \mathrm{~cm}$ sedangkan stasiun B (Muara Sungai) memiliki nilai kecerahan $20 \mathrm{~cm}$. Nilai oksigen terlarut (DO) selama penelitian berkisar antara 5,83-6,57 mg/L dengan DO tertinggi pada stasiun A (Ekosistem Mangrove) dan terendah pada stasiun B (Muara Sungai).

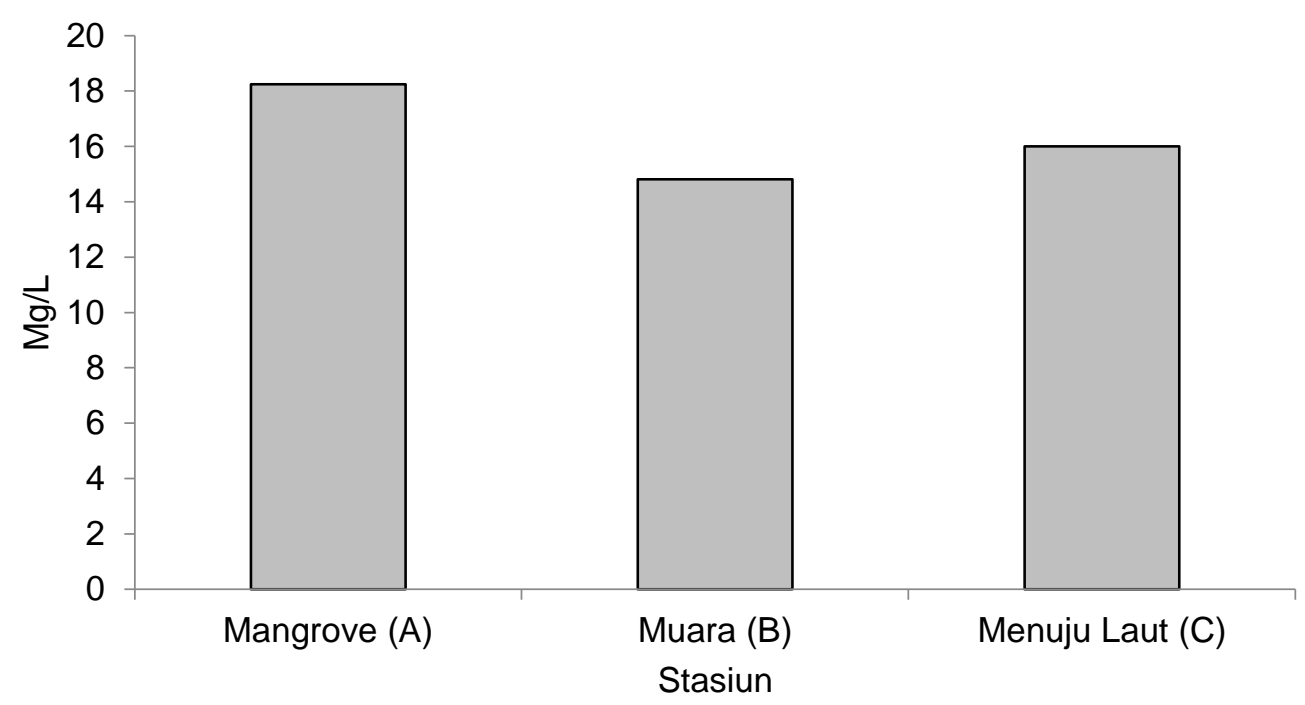

Gambar 4. Kandungan Ammonium pada Perairan Desa Bedono 


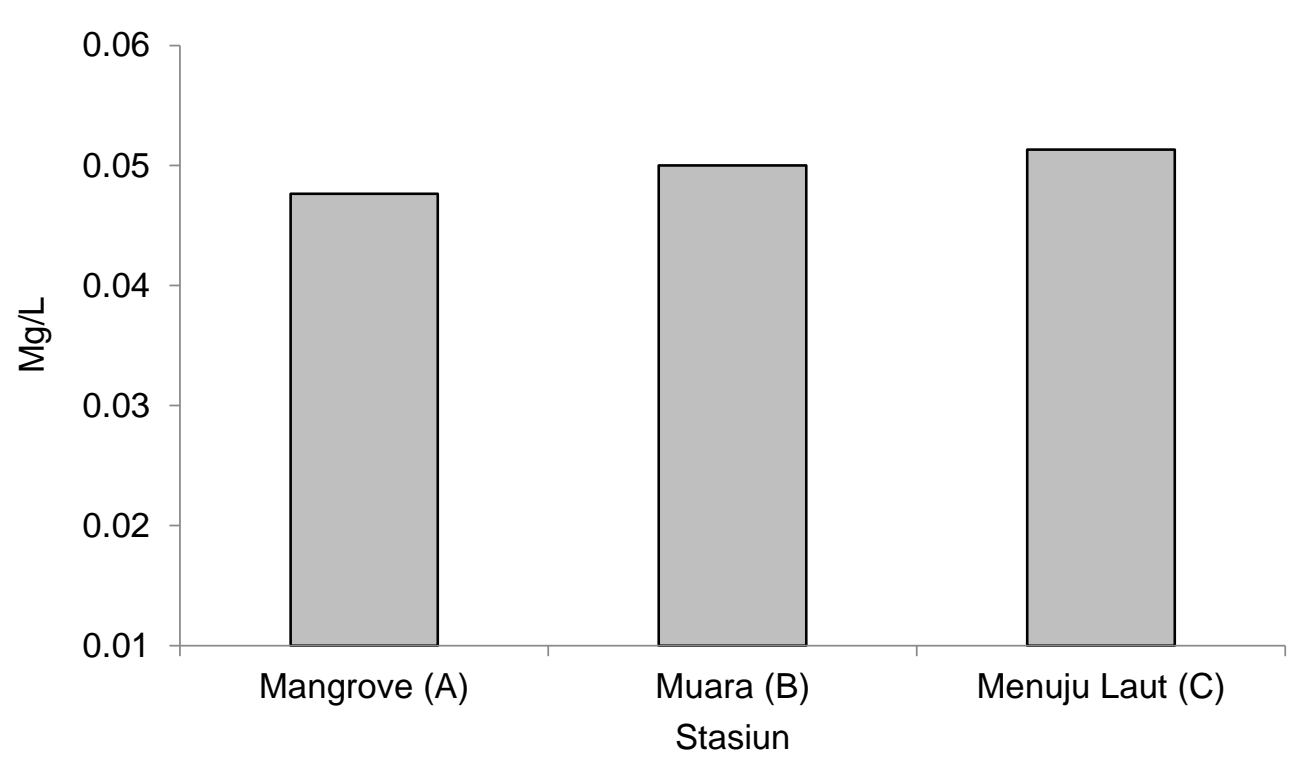

Gambar 5. Kandungan Phosphat pada Perairan Desa Bedono

\section{KESIMPULAN}

Kandungan nitrat pada perairan Desa Bedono, Kabupaten Demak berkisar antara 2,353$2,973 \mathrm{mg} / \mathrm{L}$ menunjukan nilai optimal bagi pertumbuhan fitoplankton maupun biota laut, kandungan nitrit berkisar antara 0-0,01 mg/L, kandungan ammonium berkisar antara 14,815-18,239 mg/L menunjukan nilai diatas batas optimal bagi biota laut, sedangkan kandungan phospat berkisar antara 0,4767-0,05133 $\mathrm{mg} / \mathrm{L}$. Secara umum kandungan nutrien di seluruh lokasi telah melebihi baku mutu Kemetrian Lingkungan Hidup tahun 2004 untuk biota laut dan berdasarkan kandungan nutrient nitrat dan phosphate perairan termasuk dalam level cukup subur (mesotrofik) yang berarti perairan memiliki tingkat kesuburan sedang.

\section{DAFTAR PUSTAKA}

Badan Standardisasi Nasional. 1991. SNI 06-2479-1991. Pengujian Kadar Amonium Dalam Air Dengan Alat Spektrofotometer Secara Nessler. Badan Standardisasi Nasional : Jakarta

Badan Standardisasi Nasional. 2004. SNI 06-6989.9-2004. Air dan Air Limbah - Cara Uji Nitrit $\left(\mathrm{NO}_{2}-\mathrm{N}\right)$ Secara Spektrofotometri. Badan Standardisasi Nasional : Jakarta

Badan Standardisasi Nasional. 2005. SNI 02-0086-2005. Pupuk Tripel Superfosfat. Badan Standardisasi Nasional : Jakarta

Badan Standardisasi Nasional. 2006. SNI 01-3554-2006. Cara Uji Air Minum Dalam Kemasan. Badan Standardisasi Nasional : Jakarta

Fadmawati, A.P., Supriyantini, E. \& Nuraini, R.A.T. 2017. Studi Kandungan Bahan Organik Pada Beberapa Muara Sungai Di Kawasan Ekosistem Mangrove, Di Wilayah Pesisir Pantai Utara Kota Semarang, Jawa Tengah. Buletin Oseanografi Marina, 6(1):29-38

Gurning, L.F.P., Nuraini, R.A.T., \& Suryono. 2020. Kelimpahan Fitoplankton Penyebab Harmful Algal Bloom di Perairan Desa Bedono, Demak. Journal of Marine Research, 9(3):251-260

Hadi, S. 1993. Metodologi Riset. Yayasan Penerbit Fakultas Psikologi UGM., Yogyakarta. 
Indrawati, A., Hartoko, A., \& Soedarsono, P. 2016. Hubungan Kandungan Nutrien Dalam Substrat Terhadap Kepadatan Lamun Di Perairan Desa Lalowaru Kecamatan Moramo Utara. Sapa Laut, $1(2): 42-53$

Hartoko, A., F. Prijadi S., \& Ayuningtyas I. 2013. Analisa Klorofil-A, Nitrat Dan Phospat Pada Vegetasi Mangrove Berdasarkan Data Lapangan Dan Data Satelit Geoeye Di Pulau Parang, Kepulauan Karimunjawa. Diponegoro Journal of Maquares, 2 (2): 28-37.

Hutagalung, H.P. \& Rozak, A. 1997. Metode Analisis Air Laut, Sedimen dan Biota. Buku 2. Pusat Penelitian dan Pengembangan Oseanologi LIPI, Jakarta.

Isnaeni N., Suryanti, \& Pujiono W.P. 2015. Kesuburan Perairan Berdasarkan Nitrat, Fosfat, Dan Klorofil-a Di Perairan Ekosistem Terumbu Karang Pulau Karimunjawa. Diponegoro Journal of Maquares, 4(2):75-81

Kementrian Lingkungan Hidup Republik Indonesia (KLH). 2004. Baku Mutu Air Laut Untuk Biota Laut. Keputusan Menteri Negara Lingkungan Hidup No. 51 Tahun 2004 Tentang Baku Mutu Air Laut. KLH. Jakarta.

Komarawidjaja, W., 2003. Pengaruh Aplikasi Konsorsium Mikroba Penitrifikasi Terhadap Konsentrasi Amonia (Nh3) Pada Air Tambak. Jurnal Teknologi Lingkungan, 4(2):62-67.

Kurniawan, Anna I.S.P., \& Fauziyah. 2016. Hubungan Nitrat, Phospat dan Ammonium Terhadap Keberadaan Makrozoobentos di Perairan Muara Sungai Lumpur Kapupaten Ogan Komering Ilir, Sumatera Selatan. Maspari Journal, 8(2):101-110.

Meirinawati, Hanny. 2017. Transformasi Nitrogen Di Laut. Oseana, 42(1):36 - 46

Permatasari, R.D., Djuwito \& Irwani. 2016. Pengaruh Kandungan Nitrat Dan Fosfat Terhadap Kelimpahan Diatom Di Muara Sungai Wulan, Demak. Diponegoro Journal of Maquares, 5(4):224-232

Ridwan, M., Suryono \& Nuraini, R.A.T. 2018. Studi Kandungan Nutrien Pada Ekosistem Mangrove Perairan Muara Sungai Kawasan Pesisir Semarang. Journal of Marine Research, 7(4):283-292

Risamasu, F.J. \& Hanif B.P. 2011. Kajian Zat Hara Phospat, Nitrit, Nitrat dan Silikat di Perairan Kepulauan Matasiri, Kalimantan Selatan. Indonesian Journal of Marine Sciences, 16(3):135-142

Setiani, H., Anhar, S. \& Norma, A. 2019. Hubungan Kandungan Nitrat Dan Fosfat Pada Air Dan Sedimen Terhadap Kerapatan Lamun Di Pantai Prawean Bandengan, Jepara. Diponegoro Journal of Maquares, 8(4):291-299

Subiakto, A.Y., Gunawan, W., Suryono \& Ita, R. 2019. Hubungan Kandungan Nitrat Dan Fosfat Dalam Substrat Terhadap Kerapatan Lamun Di Perairan Pantai Prawean, Jepara. Journal of Marine research, 8(1):55-61

Suryabrata, S. 1992. Metodologi Penelitian. CV Rajawali. Jakarta.

Widhitama, S., Pujiono, W.P. \& Suryanto, A. 2016. Produksi Dan Laju Dekomposisi Serasah Mangrove Berdasarkan Tingkat Kerapatannya Di Delta Sungai Wulan, Demak, Jawa Tengah. Diponegoro Journal of Maquares, 5(4):311-319

Widiyanti, V.R., Sri, S., \& Ria, A. 2018. Korelasi Kandungan Nitrat Dan Fosfat Dalam Air Dan Sedimen Dengan Kerapatan Lamun Yang Berbeda Di Perairan Teluk Awur, Jepara. Journal of Marine Research, 7(3):193-200

Wijayanto A., Pujiono W.P., \& Suryanti. 2015. Analisis Kesuburan Perairan Berdasarkan Bahan Organik Total, Nitrat, Fosfat Dan Klorofil-a Di Sungai Jajar Kabupaten Demak. Diponegoro Journal of Maquares, 4(3):76-83

Yanti, E.V. 2017. Dinamika Musiman Kualitas Air di Daerah Sungai Kahayan Kalimantan Tengah. Ziraa'ah Majalah IImiah Pertanian, 42(2):107-118. 